\title{
Multiple Muscarinic Acetylcholine Receptor Subtypes Modulate Striatal Dopamine Release, as Studied with $M_{1}-M_{5}$ Muscarinic Receptor Knock-Out Mice
}

\author{
Weilie Zhang, Masahisa Yamada, Jesus Gomeza, Anthony S. Basile, and Jürgen Wess \\ Laboratory of Bioorganic Chemistry, National Institutes of Diabetes and Digestive and Kidney Diseases, Bethesda, \\ Maryland 20892
}

\begin{abstract}
A proper balance between striatal muscarinic cholinergic and dopaminergic neurotransmission is required for coordinated locomotor control. Activation of striatal muscarinic acetylcholine receptors (mAChRs) is known to modulate striatal dopamine release. To identify the mAChR subtype(s) involved in this activity, we used genetically altered mice that lacked functional $M_{1}-M_{5}$ $\mathrm{mAChRs}$ [knock-out (KO) mice]. In superfused striatal slices from wild-type mice, the non-subtype-selective muscarinic agonist oxotremorine led to concentration-dependent increases in potassium-stimulated $\left[{ }^{3} \mathrm{H}\right]$ dopamine release (by up to $60 \%$ ). The lack of $M_{1}$ or $M_{2}$ receptors had no significant effect on the magnitude of these responses. Strikingly, oxotremorine-mediated potentiation of stimulated striatal $\left[{ }^{3} \mathrm{H}\right]$ dopamine release was abolished in $\mathrm{M}_{4}$ receptor $\mathrm{KO}$ mice, significantly increased in $\mathrm{M}_{3}$ receptor-deficient mice, and significantly reduced (but not abolished) in $M_{5}$ receptor
\end{abstract}

$\mathrm{KO}$ mice. Additional release studies performed in the presence of tetrodotoxin suggested that the dopamine release-stimulating $\mathrm{M}_{4}$ receptors are probably located on neuronal cell bodies, but that the release-facilitating $M_{5}$ and the release-inhibiting $M_{3}$ receptors are likely to be located on nerve terminals. Studies with the $\mathrm{GABA}_{\mathrm{A}}$ receptor blocker bicuculline methochloride suggested that $M_{3}$ and $\mathrm{M}_{4}$ receptors mediate their dopamine release-modulatory effects via facilitation or inhibition, respectively, of striatal GABA release. These results provide unambiguous evidence that multiple $\mathrm{mAChR}$ subtypes are involved in the regulation of striatal dopamine release. These findings should contribute to a better understanding of the important functional roles that the muscarinic cholinergic system plays in striatal function.

Key words: acetylcholine; dopamine release; knock-out mice; muscarinic receptors; oxotremorine; striatum
It is well documented that a proper balance between striatal muscarinic cholinergic and dopaminergic neurotransmission is required for coordinated locomotor control (Hornykiewicz, 1981; Graybiel, 1990; Di Chiara et al., 1994; Calabresi et al., 2000; Kaneko et al., 2000). Consistent with this concept, muscarinic antagonists are clinically useful in the treatment of Parkinson's disease (Fahn et al., 1990), a disorder caused by the relative lack of striatal dopamine resulting from the loss of dopaminergic neurons in the substantia nigra pars compacta (Hornykiewicz, 1981; Graybiel, 1990).

The release of striatal ACh from intrinsic cholinergic interneurons is modulated by dopamine via activation of different dopamine receptor subtypes (Di Chiara et al., 1994). Reciprocally, ACh-mediated activation of striatal muscarinic acetylcholine receptors (mAChRs) is known to facilitate striatal dopamine release, as has been shown in both in vitro (Lehmann and Langer, 1982; Raiteri et al., 1984; Schoffelmeer et al., 1986; Kemel et al., 1989) and in vivo (Xu et al., 1989; De Klippel et al., 1993;

\footnotetext{
Received Feb. 28, 2002; revised April 30, 2002; accepted May 7, 2002.

This work was supported by a Cooperative Research and Development Agreement between the National Institute of Diabetes and Digestive and Kidney Diseases (J.W.) and the Eli Lilly Research Laboratories.

Correspondence should be addressed to Dr. Jürgen Wess, Molecular Signaling Section, Laboratory of Bioorganic Chemistry, National Institute of Diabetes and Digestive and Kidney Diseases, National Institutes of Health, Building 8A, Room B1A-05, 8 Center Drive MSC 0810, Bethesda, MD 20892-0810. E-mail: jwess@helix.nih.gov.

M. Yamada's present address: Laboratory for Cell Culture Development, Brain Science Institute, RIKEN, Saitama 351-0198, Japan.

J. Gomeza's present address: Max-Planck-Institut für Hirnforschung, Neurochemie, Deutschordenstrasse 46, D-60528 Frankfurt/Main, Germany.

Copyright (C) 2002 Society for Neuroscience $\quad 0270-6474 / 02 / 226347-06 \$ 15.00 / 0$
}

Smolders et al., 1997) studies. Stimulation of striatal mAChRs can also result in reduced striatal dopamine release, at least under certain experimental conditions (De Belleroche and Bradford, 1978; Kemel et al., 1989; Xu et al., 1989; De Klippel et al., 1993).

The mAChR family consists of five molecularly distinct subtypes $\left(\mathrm{M}_{1}-\mathrm{M}_{5}\right)$, all of which are expressed in the striatum in a complex, overlapping manner (Weiner et al., 1990; Levey et al., 1991; Bernard et al., 1992; Yasuda et al., 1993; Hersch et al., 1994; Yan et al., 2001). From a therapeutic point of view, identification of the mAChR subtype(s) modulating striatal dopamine release should be of considerable interest. Classical pharmacological studies have led to contradictory results regarding the nature of the mAChR subtypes involved in this activity (Raiteri et al., 1984; Schoffelmeer et al., 1986; Xu et al., 1989; De Klippel et al., 1993), reflecting the limited receptor subtype selectivity of the muscarinic agonists and antagonists used in these studies (Caulfield, 1993; Wess, 1996).

To study the physiological and pathophysiological roles of individual mAChRs in a more direct manner, we (Gomeza et al., 1999a,b; Miyakawa et al., 2001; Yamada et al., 2001a,b; Fisahn et al., 2002) and others (Hamilton et al., 1997; Matsui et al., 2000; Gerber et al., 2001) used gene targeting techniques to generate $\mathrm{M}_{1}-\mathrm{M}_{5} \mathrm{mAChR}$-deficient mice. In the present study, we performed systematic dopamine release experiments using superfused striatal slices prepared from $\mathrm{M}_{1}-\mathrm{M}_{5} \mathrm{mAChR}$ knock-out (KO) mice. Specifically, we compared the effects of oxotremorine, a non-subtype-selective muscarinic agonist, on potassiumstimulated $\left[{ }^{3} \mathrm{H}\right]$ dopamine release in wild-type (WT) and $\mathrm{M}_{1}-\mathrm{M}_{5}$ mAChR KO mice.

We provide evidence that multiple mAChRs are involved in 
modulating striatal dopamine release. Our findings are consistent with the concept that stimulation of $\mathrm{M}_{4}$ and $\mathrm{M}_{5}$ receptors facilitates stimulated striatal dopamine release, whereas activation of $\mathrm{M}_{3}$ receptors inhibits this release.

\section{MATERIALS AND METHODS}

Animals. The generation of homozygous $\mathrm{M}_{1}-\mathrm{M}_{5}$ receptor $\mathrm{KO}$ mice [genetic background: $129 / \mathrm{SvEv} \times \mathrm{CF}_{1}\left(\mathrm{M}_{1}, \mathrm{M}_{3}, \mathrm{M}_{4}\right.$, and $\left.\mathrm{M}_{5}\right)$ or $129 \mathrm{~J} 1 \times$ $\mathrm{CF}_{1}\left(\mathrm{M}_{2}\right)$ ] has been described previously (Gomeza et al., 1999a,b; Yamada et al., 2001a,b; Fisahn et al., 2002). For each KO strain, the corresponding WT mice were used in parallel as controls. All experiments were performed with adult male mice that were at least 8 weeks of age. Mouse genotyping was performed by PCR analysis of mouse-tail DNA.

Dopamine release studies. Striatal slices $(250 \times 250 \mu \mathrm{m})$ prepared from one mouse were pooled and dispersed in $25 \mathrm{ml}$ of oxygenated $\left(95 \% \mathrm{O}_{2}\right.$ and $5 \% \mathrm{CO}_{2}$ ) Krebs-Ringer buffer (in mm: 11.5 glucose, $25 \mathrm{NaHCO}_{3}$, $1.2 \mathrm{MgCl}_{2}, 1.2 \mathrm{NaH}_{2} \mathrm{PO}_{4}, 118 \mathrm{NaCl}, 4.8 \mathrm{KCl}, 2.5 \mathrm{CaCl}_{2}$, and 0.004 $\mathrm{Na}_{2}$ EDTA, pH 7.4,) at $33^{\circ} \mathrm{C}$ for $20 \mathrm{~min}$. Slices were incubated with $\left[{ }^{3} \mathrm{H}\right]$ dopamine (48.2 Ci/mmol; PerkinElmer Life Sciences, Boston, MA) for $30 \mathrm{~min}$ at a final concentration of $0.2 \mu \mathrm{M}$ in the presence of the anti-oxidant ascorbate $(5 \mathrm{~mm})$ and the monoamine oxidase inhibitor pargyline $(10 \mu \mathrm{M})$ to reduce the metabolism of $\left[{ }^{3} \mathrm{H}\right]$ dopamine. To prevent the uptake of $\left[{ }^{3} \mathrm{H}\right]$ dopamine into serotonergic and noradrenergic terminals, citalopram $(1 \mu \mathrm{M})$ and desipramine $(5 \mu \mathrm{M})$ were added. After rinsing, slices were transferred to a superfusion system (SF-12; Brandel, Gaithersburg, MD) and superfused at $33^{\circ} \mathrm{C}$ at a constant rate of 0.4 $\mathrm{ml} / \mathrm{min}$. Striatal slices prepared from one mouse were aliquoted into six superfusion chambers ( $\sim 25-35$ slices per chamber), allowing the construction of complete oxotremorine concentration-response curves (Fig. 1). Fractions were collected every 4 min beginning after a $60 \mathrm{~min}$ superfusion. Two 2 min periods of $20 \mathrm{~mm} \mathrm{KCl}$ were applied after $72\left(\mathrm{~S}_{1}\right)$ and $104\left(\mathrm{~S}_{2}\right)$ min of superfusion. Tetrodotoxin (TTX) $(600 \mathrm{nM})$ was added at the beginning of superfusion when indicated. TTX is a highly selective sodium-channel blocker that blocks the conduction of action potentials along axons. This pharmacological action can be used in release assays to prevent indirect postsynaptic regulation of neurotransmitter release involving neuronal activity and can help to determine whether release-modulatory receptors are located at nerve terminals or at other cellular locations (cell bodies and/or dendrites).

Drugs were added to the superfusion buffer $20 \mathrm{~min}$ before $\mathrm{S}_{2}$. The efflux of tritium collected was calculated as a percentage of the total tritium present in the slices at the start of the fraction considered. The net efflux of tritium after $S_{1}$ (fractions 5 and 6) and $S_{2}$ (fractions 13 and 14) was calculated by subtracting the average of three fractions (expected basal value) before $\mathrm{KCl}$ stimulation $\left(\mathrm{S}_{1}\right.$, fractions $2-4 ; \mathrm{S}_{2}$, fractions 10-12). At the end of the $\left[{ }^{3} \mathrm{H}\right]$ dopamine release experiments, tissues from each chamber were solubilized with $200 \mu \mathrm{l}$ of $1 \mathrm{~N} \mathrm{NaOH}$, and tritium was determined in superfusate samples and tissues via liquid scintillation counting. The results were expressed as the $S_{2} / S_{1}$ ratio of release or as the percentage increase in $\left[{ }^{3} \mathrm{H}\right]$ dopamine release above control using the following equation: $\left\{\left[\mathrm{S}_{2} / \mathrm{S}_{1}\right.\right.$ (drug) $]-\left[\mathrm{S}_{2} / \mathrm{S}_{1}\right.$ (no drug) $]\} /\left[\mathrm{S}_{2} / \mathrm{S}_{1}\right.$ (no drug) $] \times 100$.

\section{RESULTS}

To shed light on the potential roles of striatal $M_{1}-M_{5} m A C h R s$ in modulating striatal dopamine release, we performed in vitro dopamine release studies using superfused striatal slices prepared from WT and $\mathrm{M}_{1}-\mathrm{M}_{5} \mathrm{mAChR}$-deficient mice. Initially, cellular dopamine pools were radioactively labeled by incubating striatal slices with $\left[{ }^{3} \mathrm{H}\right]$ dopamine. Subsequently, potassium $(20 \mathrm{~mm})$ stimulated $\left[{ }^{3} \mathrm{H}\right]$ dopamine release was measured either in the absence $\left(S_{1}\right.$ phase $)$ or in the presence $\left(S_{2}\right.$ phase $)$ of drugs, as described in Materials and Methods. A large body of studies indicates that such measurements yield results that are physiologically relevant (for review, see Starke et al., 1989).

Basal and potassium-stimulated $\left[{ }^{3} \mathrm{H}\right]$ dopamine outflow (approximately threefold to fourfold above basal) did not differ significantly between the individual $\mathrm{mAChR}$ KO mice and the corresponding WT controls (data not shown).
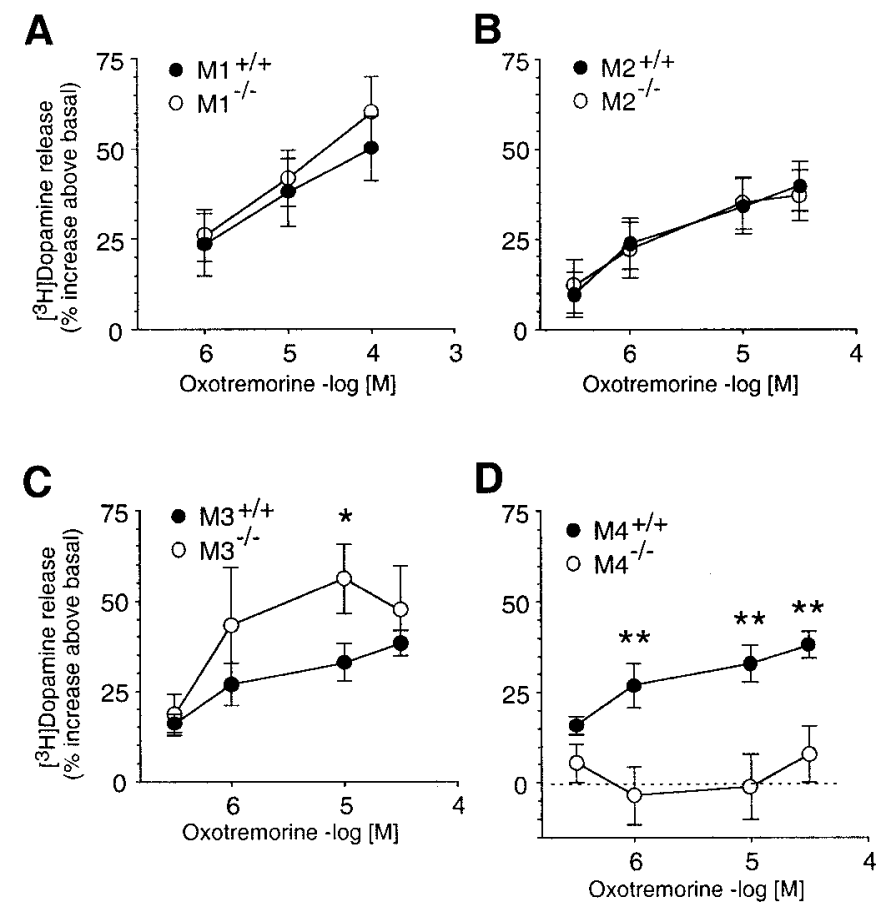

Figure 1. Effect of oxotremorine on potassium-stimulated $\left[{ }^{3} \mathrm{H}\right]$ dopamine release in striatal slices from $\mathrm{M}_{1}-\mathrm{M}_{4} \mathrm{mAChR} \mathrm{KO}$ mice and corresponding WT controls. Striatal slices that had been preincubated with $\left[{ }^{3} \mathrm{H}\right]$ dopamine were depolarized with $20 \mathrm{~mm} \mathrm{KCl}$, and the resulting $\left[{ }^{3} \mathrm{H}\right]$ dopamine outflow was quantitated in the absence and in the presence of the indicated concentrations of oxotremorine. Data are expressed as the percentage increase in $\left[{ }^{3} \mathrm{H}\right]$ dopamine release above control levels (no oxotremorine). The WT curves shown in $C$ and $D$ are identical. Because the $\mathrm{M}_{3}$ and $\mathrm{M}_{4}$ mAChR KO mice were both $129 / \mathrm{SvEv} \times \mathrm{CF}_{1}$ hybrids (50 of 50), only one WT strain of the same genetic background was tested in parallel with these mutant mice. Each data point represents the mean \pm SEM from 6-11 independent experiments (mice). Asterisks indicate significant differences between responses in $\mathrm{KO}$ versus WT preparations $\left({ }^{*} p<0.05\right.$; ${ }^{*} p<0.01$; Student's $t$ test followed by the Holm correction for multitesting adjustment).

\section{Multiple mAChRs are involved in modulating stimulated dopamine release in the striatum}

Incubation of striatal slices from WT mice with oxotremorine, a non-subtype-selective muscarinic agonist, led to concentrationdependent increases in stimulated $\left[{ }^{3} \mathrm{H}\right]$ dopamine release (maximum stimulation, $\sim 40-60 \%$ ) (Fig. 1), which is in agreement with work published previously (Lehmann and Langer, 1982; Raiteri et al., 1984; Schoffelmeer et al., 1986). This increase in dopamine release was completely abolished in the presence of atropine (10 $\mu \mathrm{M}$ ), confirming the involvement of mAChRs (data not shown).

As shown in Figure $1 A, B$, the lack of $\mathrm{M}_{1}$ or $\mathrm{M}_{2}$ receptors had no significant effect on oxotremorine-mediated increases in $\left[{ }^{3} \mathrm{H}\right]$ dopamine output. However, this response was significantly enhanced in striatal preparations from $\mathrm{M}_{3}$ receptor $\mathrm{KO}$ mice (Fig. $1 C)(p<0.05$ at $10 \mu \mathrm{M}$ oxotremorine), suggesting that the activation of striatal $\mathrm{M}_{3}$ receptors has an inhibitory effect on stimulated dopamine release in WT mice. Strikingly, the ability of oxotremorine to facilitate stimulated striatal $\left[{ }^{3} \mathrm{H}\right]$ dopamine release was totally abolished in $\mathrm{M}_{4}$ receptor $\mathrm{KO}$ mice (Fig. 1D). Similar results were obtained with striatal slices prepared from $\mathrm{M}_{2} / \mathrm{M}_{4}$ receptor double $\mathrm{KO}$ mice (data not shown). These findings indicate that $\mathrm{M}_{4}$ receptors play a key role in promoting $\mathrm{mAChR}$-dependent increases in striatal dopamine output. 
A

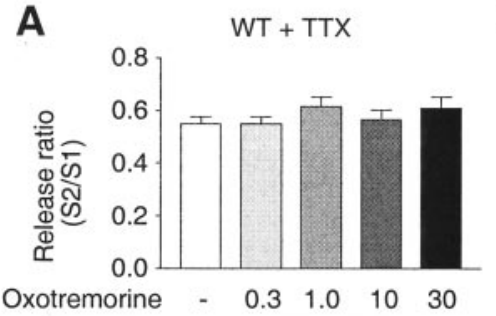

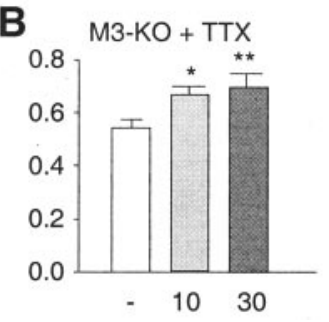

Figure 2. Effect of TTX on oxotremorine-mediated modulation of potassium-stimulated $\left[{ }^{3} \mathrm{H}\right]$ dopamine release in striatal slices from WT and $\mathrm{M}_{3}$ receptor KO mice. In the presence of TTX $(600 \mathrm{nM})$, oxotremorine had no significant effect on stimulated $\left[{ }^{3} \mathrm{H}\right]$ dopamine release in WT preparations $(A)$ but induced a significant enhancement in $\left[{ }^{3} \mathrm{H}\right]$ dopamine output in striatal slices from $\mathrm{M}_{3}$ receptor $\mathrm{KO}$ mice $(B)$. Each bar represents the mean \pm SEM of $S_{2} / S_{1}$ values from six or seven independent experiments (mice). Micromolar concentrations are shown. Asterisks indicate significant differences from the control group (no oxotremorine) $\left({ }^{*} p<0.05{ }^{* *} p<0.01\right.$; one-way ANOVA followed by Dunnett's test).

We have reported previously that oxotremorine-mediated enhancement of striatal dopamine release was impaired (but not abolished) in striatal slices derived from $\mathrm{M}_{5}$ receptor $\mathrm{KO}$ mice (Yamada et al., 2001a). Together, these data clearly indicate that multiple mAChRs are involved in modulating the magnitude of stimulated dopamine release in the mouse striatum.

\section{TTX has differential effects on oxotremorine-mediated modulation of simulated striatal dopamine release in WT and $M_{3}$ and $M_{5}$ receptor KO mice}

We then wanted to investigate whether mAChR-mediated modulation of stimulated striatal dopamine release was dependent on the activation of mAChRs on (dopaminergic) nerve terminals or whether it required more complex neuronal circuits. To address this issue, we examined to what extent oxotremorine-mediated modulation of striatal dopamine release was altered in the presence of TTX, a selective sodium-channel blocker that prevents the propagation of action potentials along axons.

In the presence of TTX (600 nM), oxotremorine-mediated increases in potassium-stimulated $\left[{ }^{3} \mathrm{H}\right]$ dopamine release were abolished in striatal preparations from WT mice (Fig. $2 A$ ). Interestingly, TTX treatment unmasked opposing modulatory effects of oxotremorine on stimulated $\left[{ }^{3} \mathrm{H}\right]$ dopamine release in striatal preparations from $\mathrm{M}_{3}$ and $\mathrm{M}_{5}$ receptor $\mathrm{KO}$ mice. In tissues from $\mathrm{M}_{3}$ receptor $\mathrm{KO}$ mice, oxotremorine (in the presence of TTX) retained the ability to induce small but significant increases in potassium-stimulated $\left[{ }^{3} \mathrm{H}\right]$ dopamine release (Fig. $2 B$ ), most likely because of the presence of release-facilitating $\mathrm{M}_{5}$ receptors and the absence of release-inhibiting $\mathrm{M}_{3}$ receptors. However, in preparations from $\mathrm{M}_{5}$ receptor $\mathrm{KO}$ mice, oxotremorine treatment (in the presence of TTX) significantly decreased potassium-stimulated $\left[{ }^{3} \mathrm{H}\right]$ dopamine release (Fig. $3 A$ ), probably because of the presence of release-inhibiting $\mathrm{M}_{3}$ and the absence of release-facilitating $\mathrm{M}_{5}$ receptors.

In the striatum, $\mathrm{M}_{3}$ receptors are expressed by a subgroup of GABAergic projection neurons (Hersch et al., 1994; Yan et al., 2001), raising the possibility that the release-inhibiting effects of $\mathrm{M}_{3}$ receptors that persist in the presence of TTX are attributable to an increase in GABA release. Consistent with this hypothesis, the incubation of TTX-treated striatal slices from $\mathrm{M}_{5}$ receptor $\mathrm{KO}$ mice with the $\mathrm{GABA}_{\mathrm{A}}$ receptor antag-
A

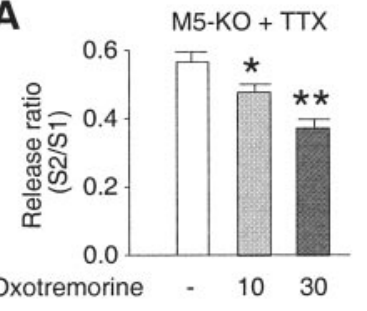

B

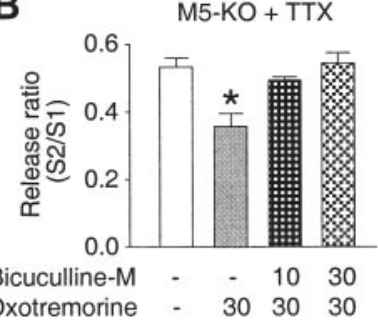

Figure 3. Effect of TTX on oxotremorine-mediated modulation of potassium-stimulated $\left[{ }^{3} \mathrm{H}\right]$ dopamine release in striatal slices from $\mathrm{M}_{5}$ receptor KO mice. In the presence of TTX $(600 \mathrm{nM})$, oxotremorine induced a decrease in potassium-stimulated $\left[{ }^{3} \mathrm{H}\right]$ dopamine release in striatal slices from $\mathrm{M}_{5}$ receptor KO mice $(A)$. This effect was blocked by the $\mathrm{GABA}_{\mathrm{A}}$ receptor antagonist bicuculline methochloride $(B)$. Each bar represents the mean \pm SEM of $S_{2} / S_{1}$ values from eight independent experiments (mice). Micromolar concentrations are shown. Asterisks indicate significant differences from the control group (no drug) $\left({ }^{*} p<0.05\right.$; ${ }_{* *}^{* *}<0.01$; one-way ANOVA followed by Dunnett's test).

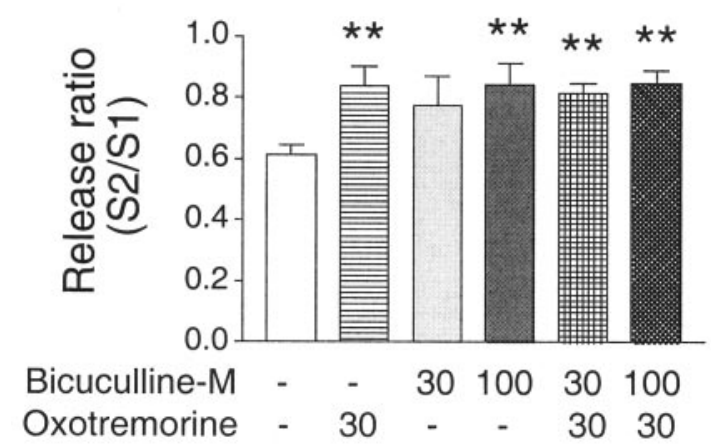

Figure 4. Effect of the $\mathrm{GABA}_{\mathrm{A}}$ receptor antagonist bicuculline methochloride on oxotremorine-mediated enhancement of potassium-stimulated $\left[{ }^{3} \mathrm{H}\right]$ dopamine release in striatal slices from WT mice. When administered alone, bicuculline methochloride $(100 \mu \mathrm{M})$ mimicked the release-facilitating effect of oxotremorine; however, when coadministered with oxotremorine, bicuculline methochloride did not further enhance $\left[{ }^{3} \mathrm{H}\right]$ dopamine output. Each bar represents the mean \pm SEM of $\mathrm{S}_{2} / \mathrm{S}_{1}$ values from eight independent experiments (mice). Micromolar concentrations are shown. Asterisks indicate significant differences from the control group (no drug) $(* * p<$ 0.01; one-way ANOVA followed by Dunnett's test).

onist bicuculline methochloride (10 and $30 \mu \mathrm{M})$ completely prevented oxotremorine $(30 \mu \mathrm{M})$-mediated inhibition of dopamine release (Fig. 3B).

As outlined above, oxotremorine lacked the ability to facilitate stimulated dopamine release in striatal slices from $\mathrm{M}_{4}$ receptor $\mathrm{KO}$ mice (Fig. $1 D$ ). In the striatum, $\mathrm{M}_{4}$ receptors are abundantly expressed by GABAergic projection neurons (Weiner et al., 1990; Bernard et al., 1992; Hersch et al., 1994; Santiago and Potter, 2001). Therefore, we speculated that the dopamine release-facilitating activity of $\mathrm{M}_{4}$ receptors might be attributable to $\mathrm{M}_{4}$ receptor-mediated reductions in GABA release. In agreement with this hypothesis, incubation of striatal slices from WT mice with bicuculline methochloride (100 $\mu \mathrm{M})$ mimicked the stimulatory effect of oxotremorine $(30 \mu \mathrm{M})$ on potassium-induced $\left[{ }^{3} \mathrm{H}\right]$ dopamine release (Fig. 4). Combining bicuculline methochloride (30 or $100 \mu \mathrm{M}$ ) and oxotremorine $(30 \mu \mathrm{M})$ did not increase the stimulated $\left[{ }^{3} \mathrm{H}\right]$ dopamine outflow from WT preparations any more than observed with either drug alone (Fig. 4). 


\section{DISCUSSION}

Properly regulated dopamine release in the striatum is of fundamental importance for extrapyramidal locomotor control (Graybiel, 1990; Di Chiara et al.; 1994; Calabresi et al., 2000). The present study was designed to identify specific mAChR subtypes involved in modulating this process. Previous studies using classical pharmacological tools have led to conflicting results regarding the molecular identity of the mAChR subtypes involved in the regulation of striatal dopamine release, probably because of the limited degree of receptor subtype selectivity of the muscarinic agonists and antagonists used in these studies. For example, although it has been proposed that muscarinic agonist-induced enhancement of striatal dopamine release is mediated by $M_{1}$ receptors (Raiteri et al., 1984; Xu et al., 1989; Smolders et al., 1997), Schoffelmeer et al. (1986) suggested that this activity is dependent on the stimulation of non- $\mathrm{M}_{1} \mathrm{mAChRs}$. However, it has been proposed that muscarinic agonist-induced inhibition of striatal dopamine release is mediated by $\mathrm{M}_{2}$ receptors (Xu et al., 1989; De Klippel et al., 1993).

Receptor localization studies have shown that all five mAChRs $\left(\mathrm{M}_{1}-\mathrm{M}_{5}\right)$ are expressed in the striatum (Weiner et al., 1990; Bernard et al., 1992; Yasuda et al., 1993; Hersch et al., 1994; Yan et al., 2001), raising the possibility that multiple mAChRs play a role in the modulation of striatal dopamine release. To address this issue in a more direct manner, we performed systematic dopamine release studies using superfused striatal slices from $\mathrm{M}_{1}-\mathrm{M}_{5} \mathrm{mAChR}$-deficient mice. Previous studies have shown that disruption of specific $\mathrm{mAChR}$ genes has no significant effect on the expression levels of the remaining four $\mathrm{mAChR}$ subtypes in different regions of the brain, including the striatum (Hamilton et al., 1997; Gomeza et al., 1999a,b; Miyakawa et al., 2001; Yamada et al., 2001b; Fisahn et al., 2002; Zhang et al., 2002).

Consistent with previous findings (Lehmann and Langer, 1982; Raiteri et al., 1984; Schoffelmeer et al., 1986), incubation of WT striatal slices with the non-subtype-selective muscarinic agonist oxotremorine led to concentration-dependent increases in potassium-stimulated $\left[{ }^{3} \mathrm{H}\right]$ dopamine release (Fig. 1). The magnitude of this response was not affected by the lack of $\mathrm{M}_{1}$ or $\mathrm{M}_{2}$ receptors (as studied with $\mathrm{M}_{1}$ and $\mathrm{M}_{2}$ receptor $\mathrm{KO}$ mice) (Fig. 1 $A, B$ ), both of which are expressed at relatively high levels in the striatum (Weiner et al., 1990; Levey et al., 1991; Bernard et al., 1992; Hersch et al., 1994). These results clearly indicate that striatal $\mathrm{M}_{1}$ and $\mathrm{M}_{2}$ receptors do not play a significant role in the regulation of striatal dopamine output, in contrast to the conclusions drawn based on classical pharmacological studies using muscarinic ligands of limited receptor subtype selectivity.

Interestingly, in vivo microdialysis studies showed recently that $\mathrm{M}_{1}$ receptor-deficient mice have significantly elevated levels of extracellular dopamine in the striatum, probably because of increased dopamine release (Gerber et al., 2001). As discussed by Gerber et al. (2001), it is possible that the $\mathrm{M}_{1}$ receptors modulating striatal dopamine release are located on either striatal or extrastriatal (e.g., cortical) neurons projecting to the striatum. Because the lack of $\mathrm{M}_{1}$ receptors had no significant effect on basal or stimulated dopamine release in striatal slice preparations (this study), the increase in extracellular dopamine levels observed in vivo is most likely attributable to the absence of extrastriatal (e.g., cortical) $M_{1}$ receptors mediating inhibition of striatal dopamine release through an indirect neuronal pathway.
Strikingly, muscarinic agonist-mediated increases in stimulated $\left[{ }^{3} \mathrm{H}\right]$ dopamine output were totally abolished in striatal slices from $\mathrm{M}_{4}$ receptor $\mathrm{KO}$ mice (Fig. $1 D$ ), suggesting that $\mathrm{M}_{4}$ receptors play a key role in mediating this activity. Similarly, TTX treatment (600 nM) of WT striatal slices also completely abolished the dopamine release-facilitating effects of oxotremorine (Fig. 2A), suggesting that this activity requires the propagation of action potentials. In the striatum, $\mathrm{M}_{4}$ receptors are abundantly expressed by medium spiny GABAergic projection neurons (Weiner et al., 1990; Bernard et al., 1992; Hersch et al., 1994; Santiago and Potter, 2001), where they are preferentially located on cell bodies and dendritic shafts and spines (Hersch et al., 1994; Bernard et al., 1999). $\mathrm{M}_{4}$ receptors, like $\mathrm{M}_{2}$ receptors, are coupled to $\mathrm{G}$-proteins of the $\mathrm{G}_{\mathrm{i}} / \mathrm{G}_{\mathrm{o}}$ family, which, among other cellular effects, can reduce neuronal activity by inhibiting different classes of calcium channels (Caulfield, 1993; Hille, 1994; Howe and Surmeier, 1995). Interestingly, in WT striatal slices, the $\mathrm{GABA}_{\mathrm{A}}$ receptor antagonist bicuculline methochloride mimicked the release-facilitating effect of oxotremorine when administered alone; however, when coadministered with oxotremorine, bicuculline methochloride did not further enhance $\left[{ }^{3} \mathrm{H}\right]$ dopamine output (Fig. 4). Together, these observations are consistent with a model in which the activation of $\mathrm{M}_{4}$ receptors present on GABAergic projection neurons inhibits GABA release, resulting in reduced $\mathrm{GABA}_{\mathrm{A}}$ receptor-mediated inhibition of dopamine release from dopaminergic nerve endings. This model is supported by previous studies that indicate that muscarinic agonists inhibit GABA release in the striatum (Marchi et al., 1990; Sugita et al., 1991), that dopaminergic neurons in the substantia nigra receive synaptic input from striatal GABAergic neurons (Bolam and Smith, 1990), that dopamine release-inhibiting $\mathrm{GABA}_{\mathrm{A}}$ receptors exist on dopaminergic striatal nerve endings (Ronken et al., 1993), and that ACh-mediated enhancement of striatal $\left[{ }^{3} \mathrm{H}\right]$ dopamine release may be mediated by the collaterals of GABAergic inhibitory neurons (Kemel et al., 1989).

We have reported previously that oxotremorine-mediated potentiation of stimulated dopamine release was significantly reduced (by $\sim 50 \%$ ) at an intermediate oxotremorine concentration $(10 \mu \mathrm{M})$ in striatal slices derived from $\mathrm{M}_{5}$ receptor $\mathrm{KO}$ mice (Yamada et al., 2001a), suggesting that $M_{5}$ receptors also contribute to ACh-mediated enhancement of striatal dopamine release. However, maximum oxotremorine responses were not significantly affected by the lack of $\mathrm{M}_{5}$ receptors (Yamada et al., 2001a), in contrast to the total lack of oxotremorine activity observed in the absence of $\mathrm{M}_{4}$ receptors (Fig. $1 D$ ).

In contrast, oxotremorine-mediated enhancement of stimulated $\left[{ }^{3} \mathrm{H}\right]$ dopamine release was significantly increased in striatal slices from $\mathrm{M}_{3}$ receptor $\mathrm{KO}$ mice (Fig. $1 C$ ), indicating that $\mathrm{M}_{3}$ receptor stimulation activates a pathway that inhibits striatal dopamine release. The opposing effects of $M_{3}$ versus $M_{5}$ receptor stimulation on striatal dopamine release may explain the observation that oxotremorine had no net effect on stimulated dopamine release in striatal slices from $\mathrm{M}_{4}$ receptor $\mathrm{KO}$ mice (Fig. $1 D$ ).

When release studies were performed in the presence of TTX (which is predicted to block the $\mathrm{M}_{4}$ receptor-mediated enhancement of dopamine release), oxotremorine administration led to small but significant increases in stimulated dopamine release in striatal slices from $\mathrm{M}_{3}$ receptor $\mathrm{KO}$ mice (Fig. $2 B$ ) but to a significant decrease in dopamine output in preparations from $\mathrm{M}_{5}$ receptor $\mathrm{KO}$ mice (Fig. $3 A$ ). These observations provide additional support for the concept that $\mathrm{M}_{3}$ and $\mathrm{M}_{5}$ receptors mediate opposing effects on stimulated dopamine release in the striatum. 
Because $M_{3}$ and $M_{5}$ receptor-mediated modulation of striatal dopamine release persists in the presence of TTX, it is likely that the $M_{3}$ and $M_{5}$ receptors involved in this activity are located on nerve terminals.

$\mathrm{M}_{5}$ receptor mRNA is the only mAChR subtype mRNA detectable in the dopamine-containing cells of the substantial nigra pars compacta (Vilaro et al., 1990; Weiner et al., 1990), strongly suggesting that the dopamine release-facilitating $\mathrm{M}_{5}$ receptors are located on dopaminergic nerve terminals. Based on these findings (Vilaro et al., 1990; Weiner et al., 1990), together with the fact that $M_{3}$ and $M_{5}$ receptors (as well as $M_{1}$ receptors) couple to a similar set of $\mathrm{G}$-proteins $\left(\mathrm{G}_{\mathrm{q}}\right.$ family) (Caulfield, 1993; Wess, 1996), it is unlikely that the dopamine releaseinhibiting $\mathrm{M}_{3}$ receptors are colocalized with $\mathrm{M}_{5}$ receptors on dopaminergic terminals. $\mathrm{M}_{3}$ receptors are expressed, although apparently at relatively low levels, in a subset of GABAergic projection neurons (Hersch et al., 1994; Yan et al., 2001), raising the possibility that $\mathrm{M}_{3}$ receptors located on GABAergic nerve terminals inhibit dopamine release by stimulating GABA release. Consistent with this concept, the $\mathrm{GABA}_{\mathrm{A}}$ receptor antagonist bicuculline methochloride completely blocked the oxotremorine-mediated reduction in dopamine release observed with TTX-treated striatal slices from $\mathrm{M}_{5}$ receptor KO mice (Fig. $3 B$ ). The existence of presynaptic striatal $\mathrm{M}_{3}$ receptors has also been demonstrated via immunoelectron microscopy (Hersch et al., 1994).

In summary, our data provide strong evidence that multiple $\mathrm{mAChR}$ subtypes are involved in the regulation of striatal dopamine release. Whereas activation of $M_{4}$ and $M_{5}$ receptors facilitates striatal dopamine release, stimulation of $\mathrm{M}_{3}$ receptors inhibits this process. Striatal $\mathrm{M}_{1}$ and $\mathrm{M}_{2}$ receptors do not seem to play significant roles in modulating striatal dopamine output. Our results underscore the usefulness of muscarinic receptor mutant mice to delineate the roles of individual mAChR subtypes in the regulation of striatal function. A better understanding of the role of the striatal muscarinic cholinergic system may open new perspectives for the treatment of Parkinson's disease and other extrapyramidal movement disorders.

\section{REFERENCES}

Bernard V, Normand E, Bloch B (1992) Phenotypical characterization of the rat striatal neurons expressing muscarinic receptor genes. J Neurosci 12:3591-3600.

Bernard V, Levey AI, Bloch B (1999) Regulation of the subcellular distribution of $\mathrm{m} 4$ muscarinic acetylcholine receptors in striatal neurons in vivo by the cholinergic environment: evidence for regulation of cell surface receptors by endogenous and exogenous stimulation. J Neurosci 19:10237-10249.

Bolam JP, Smith Y (1990) The GABA and substance P input to dopaminergic neurones in the substantia nigra of the rat. Brain Res 529:57-78.

Calabresi P, Centonze D, Gubellini P, Pisani A, Bernardi G (2000) Acetylcholine-mediated modulation of striatal function. Trends Neurosci 23:120-126.

Caulfield MP (1993) Muscarinic receptors: characterization, coupling, and function. Pharmacol Ther 58:319-379.

De Belleroche J, Bradford HF (1978) Biochemical evidence for the presence of presynaptic receptors on dopaminergic nerve terminals. Brain Res 142:53-68.

De Klippel N, Sarre S, Ebinger G, Michotte Y (1993) Effect of M1- and M2-muscarinic drugs on striatal dopamine release and metabolism: an in vivo microdialysis study comparing normal and 6-hydroxydopaminelesioned rats. Brain Res 630:57-64.

Di Chiara G, Morelli M, Consolo S (1994) Modulatory functions of neurotransmitters in the striatum: ACh/dopamine/NMDA interactions. Trends Neurosci 17:228-233.

Fahn S, Burke R, Stern Y (1990) Antimuscarinic drugs in the treatment of movement disorders. Prog Brain Res 84:389-397.

Fisahn A, Yamada M, Duttaroy A, Gan J-W, Deng C-X, McBain CJ,
Wess J (2002) Muscarinic induction of hippocampal $\gamma$ oscillations requires coupling of the M1 receptor to two mixed cation channels. Neuron 33:615-624.

Gerber DJ, Sotnikova TD, Gainetdinov RR, Huang SY, Caron MG, Tonegawa S (2001) Hyperactivity, elevated dopaminergic transmission, and response to amphetamine in M1 muscarinic acetylcholine receptor-deficient mice. Proc Natl Acad Sci USA 98:15312-15317.

Gomeza J, Shannon H, Kostenis E, Felder C, Zhang L, Brodkin J, Grinberg A, Sheng H, Wess J (1999a) Pronounced pharmacologic deficits in M2 muscarinic acetylcholine receptor knockout mice. Proc Natl Acad Sci USA 96:1692-1697.

Gomeza J, Zhang L, Kostenis K, Felder C, Bymaster F, Brodkin J, Shannon H, Xia B, Deng C, Wess J (1999b) Enhancement of D1 dopamine receptor-mediated locomotor stimulation in $\mathrm{M}_{4}$ muscarinic acetylcholine receptor knockout mice. Proc Natl Acad Sci USA 96:10483-10488.

Graybiel AM (1990) Neurotransmitters and neuromodulators in the basal ganglia. Trends Neurosci 13:244-254.

Hamilton SE, Loose MD, Qi M, Levey AI, Hille B, McKnight GS, Idzerda RL, Nathanson NM (1997) Disruption of the m1 receptor gene ablates muscarinic receptor-dependent $\mathrm{M}$ current regulation and seizure activity in mice. Proc Natl Acad Sci USA 94:13311-13316.

Hersch S, Gutekunst C-A, Rees HD, Heilman CJ, Levey AI (1994) Distribution of $\mathrm{m} 1-\mathrm{m} 4$ muscarinic receptor proteins in the rat striatum: light and electron microscopic immunocytochemistry using subtypespecific antibodies. J Neurosci 14:3351-3363.

Hille B (1994) Modulation of ion-channel function by G-protein-coupled receptors. Trends Neurosci 17:531-536.

Hornykiewicz O (1981) Brain neurotransmitter changes in Parkinson's disease. In: Movement disorders (Marsden DC, Fahn S, eds), pp 41-58. Boston: Butterworth.

Howe AR, Surmeier DJ (1995) Muscarinic receptors modulate N-, P-, and L-type $\mathrm{Ca}^{2+}$ currents in rat striatal neurons through parallel pathways. J Neurosci 15:458-469.

Kaneko S, Hikida T, Watanabe D, Ichinose H, Nagatsu T, Kreitman RJ, Pastan I, Nakanishi S (2000) Synaptic integration mediated by striatal cholinergic interneurons in basal ganglia function. Science 289:633-637.

Kemel M-L, Desban M, Glowinski J, Gauchyh C (1989) Distinct presynaptic control of dopamine release in striosomal and matrix areas of the cat caudate nucleus. Proc Natl Acad Sci USA 86:9006-9010.

Lehmann J, Langer SZ (1982) Muscarinic receptors on dopamine terminals in the cat caudate nucleus: neuromodulation of $\left[{ }^{3} \mathrm{H}\right]$ dopamine release in vitro by endogenous acetylcholine. Brain Res 248:61-69.

Levey AI, Kitt CA, Simonds WF, Price DL, Brann MR (1991) Identification and localization of muscarinic acetylcholine receptor proteins in brain with subtype-specific antibodies. J Neurosci 11:3218-3226.

Marchi M, Sanguineti P, Raiteri M (1990) Muscarinic receptors mediate direct inhibition of GABA release from rat striatal nerve terminals. Neurosci Lett 116:347-351.

Matsui M, Motomura D, Karasawa H, Fujikawa T, Jiang J, Komiya Y, Takahashi S, Taketo MM (2000) Multiple functional defects in peripheral autonomic organs in mice lacking muscarinic acetylcholine receptor gene for the M3 subtype. Proc Natl Acad Sci USA 97:9579-9584.

Miyakawa T, Yamada M, Duttaroy A, Wess J (2001) Hyperactivity and intact hippocampus-dependent learning in mice lacking the $\mathrm{M}_{1}$ muscarinic acetylcholine receptor. J Neurosci 21:5239-5250.

Raiteri M, Leardi R, Marchi M (1984) Heterogeneity of presynaptic muscarinic receptors regulating neurotransmitter release in the rat brain. J Pharmacol Exp Ther 228:209-214.

Ronken E, Mulder AH, Schoffelmeer AN (1993) Interacting presynaptic $\kappa$-opioid and $\mathrm{GABA}_{\mathrm{A}}$ receptors modulate dopamine release from rat striatal synaptosomes. J Neurochem 61:1634-1639.

Santiago MP, Potter LT (2001) Biotinylated m4-toxin demonstrates more M4 muscarinic receptor protein on direct than indirect striatal projection neurons. Brain Res 894:12-20.

Schoffelmeer AN, Van Vliet BJ, Wardeh G, Mulder AH (1986) Muscarine receptor-mediated modulation of $\left[{ }^{3} \mathrm{H}\right]$ dopamine and $\left[{ }^{14} \mathrm{C}\right]$ acetylcholine release from rat neostriatal slices: selective antagonism by gallamine but not pirenzepine. Eur J Pharmacol 128:291-294.

Smolders I, Bogaert L, Ebinger G, Michotte Y (1997) Muscarinic modulation of striatal dopamine, glutamate, and GABA release, as measured with in vivo microdialysis. J Neurochem 68:1942-1948.

Starke K, Göthert M, Kilbinger H (1989) Modulation of neurotransmitter release by presynaptic autoreceptors. Physiol Rev 69:864-989.

Sugita S, Uchimura N, Jiang ZG, North RA (1991) Distinct muscarinic receptors inhibit release of $\gamma$-aminobutyric acid and excitatory amino acids in mammalian brain. Proc Natl Acad Sci USA 88:2608-2611.

Vilaro MT, Palacios JM, Mengod G (1990) Localization of m5 muscarinic receptor mRNA in rat brain examined by in situ hybridization histochemistry. Neurosci Lett 114:154-159.

Weiner DM, Levey AI, Brann MR (1990) Expression of muscarinic acetylcholine and dopamine receptor mRNAs in rat basal ganglia. Proc Natl Acad Sci USA 87:7050-7054. 
Wess J (1996) Molecular biology of muscarinic acetylcholine receptors. Crit Rev Neurobiol 10:69-99.

Xu M, Mizobe F, Yamamoto T, Kato T (1989) Differential effects of M1and M2-muscarinic drugs on striatal dopamine release and metabolism in freely moving rats. Brain Res 495:232-242.

Yamada M, Lamping KG, Duttaroy A, Zhang W, Cui Y, Bymaster FP, McKinzie DL, Felder CC, Deng CX, Faraci FM, Wess J (2001a) Cholinergic vasodilation of cerebral blood vessels is abolished in $\mathbf{M}_{5}$ muscarinic acetylcholine receptor knockout mice. Proc Natl Acad Sci USA 98:14096-14101.

Yamada M, Miyakawa T, Duttaroy A, Yamanaka A, Moriguchi T, Makita R, Ogawa M, Chou CJ, Xia B, Crawley JN, Felder CC, Deng CX, Wess
J (2001b) Mice lacking the M3 muscarinic acetylcholine receptor are hypophagic and lean. Nature 410:207-212.

Yan Z, Flores-Hernandez J, Surmeier DJ (2001) Coordinated expression of muscarinic receptor messenger RNAs in striatal medium spiny neurons. Neuroscience 103:1017-1024.

Yasuda RP, Ciesla W, Flores LR, Wall SJ, Li M, Satkus SA, Weisstein JS, Spagnola BV, Wolfe BB (1993) Development of antisera selective for $\mathrm{m} 4$ and $\mathrm{m} 5$ muscarinic cholinergic receptors: distribution of $\mathrm{m} 4$ and $\mathrm{m} 5$ receptors in rat brain. Mol Pharmacol 43:149-157.

Zhang W, Basile AS, Gomeza J, Volpicelli LA, Levey AI, Wess J (2002) Characterization of central inhibitory muscarinic autoreceptors by the use of muscarinic acetylcholine receptor knock-out mice. J Neurosci 22:1709-1717. 